\title{
CHEMICAL, ANTIOXIDANT AND IN VITRO PERMEATION AND PENETRATION STUDIES OF EXTRACTS OBTAINED FROM VIBURNUM OPULUS AND CRATAEGUS PENTAGYNA
}

\author{
ALEXANDRA BUJOR ${ }^{1}$, LĂCRĂMIOARA OCHIUZ ${ }^{1 *}$, MOUSA SHA'AT ${ }^{1}$, IULIAN STOLERIU $^{2}$, \\ STAMATE MONICA ILIUŢA ${ }^{1}$, SIMON VLAD LUCA ${ }^{1,3}$, ANCA MIRON $^{1}$ \\ ${ }^{I}$ Faculty of Pharmacy, "Grigore T. Popa” University of Medicine and Pharmacy, 16 Universităţii Street, 700115, Iaşi, \\ Romania \\ ${ }^{2}$ Faculty of Mathematics, "Alexandru I. Cuza” University, 11 Carol I Boulevard, 700506, Iaşi, Romania \\ ${ }^{3}$ Biothermodynamics, TUM School of Life Sciences Weihenstephan, Technical University of Munich, Maximus-von-Imhof- \\ Forum 2, 85354, Freising, Germany
}

*corresponding author: lacramioara.ochiuz@umfiasi.ro

Manuscript received: February 2020

\begin{abstract}
The purposes of the study were the comparison between the levels of different polyphenol groups in Crataegus pentagyna (CP) leaf and Viburnum opulus (VO) fruit extracts, the assessment of their 2,2-diphenyl-1-picrylhydrazyl (DPPH) radical scavenging activity and the in vitro determination of their permeability parameters. CP extract had higher total phenolic, flavonoid and proanthocyanidin contents than VO extract (901.12 $\pm 3.23 \mathrm{vs} .231 .15 \pm 1.53 \mathrm{mg}$ chlorogenic acid equivalents $/ \mathrm{g}$ extract, $416.68 \pm 2.03$ vs. $95.33 \pm 0.95 \mathrm{mg}$ catechin equivalents $/ \mathrm{g}$ extract and $112.7 \pm 1.21 \mathrm{vs} .18 .40 \pm 0.87 \mathrm{mg}$ cyanidin/g extract, respectively), while both extracts showed promising DPPH scavenging activity (EC50 $=15.56 \pm 0.03$ and $47.18 \pm$ $0.12 \mu \mathrm{g} / \mathrm{mL}$, respectively). To investigate whether the sublingual or cutaneous routes are suitable for the administration of $\mathrm{CP}$ and VO extracts, permeation and penetration studies were carried out in Franz diffusion cells. The polyphenols of CP and VO extracts had higher transfer across the sublingual porcine membrane $(71.93 \%$ and $62.65 \%$ polyphenols in the receptor compartment, respectively) than across the chicken skin membrane ( $54.48 \%$ and $39.42 \%$ polyphenols in the receptor compartment, respectively). The results provide evidence that these extracts can be used to develop oromucosal dosage forms.
\end{abstract}

\section{Rezumat}

Obiectivele studiului au constat în compararea conținutului diferitelor clase de polifenoli din extractele obținute din frunzele de Crataegus pentagyna (CP) și fructele de Viburnum opulus (VO), evaluarea capacității extractelor de a inactiva radicalul liber DPPH (2,2-difenil-1-picrilhidrazil), precum și determinarea in vitro a parametrilor de permeabilitate pentru ambele extracte. Extractul CP s-a remarcat prin conținutul în polifenoli totali, flavonoide și proantocianidoli mai crescut decât al extractului VO $(901,12 \pm 3,23$ vs. $231,15 \pm 1,53 \mathrm{mg}$ echivalenți acid clorogenic/g extract, 416,68 $\pm 2,03$ vs. 95,33 $\pm 0,95 \mathrm{mg}$ echivalenți catehină/g extract și respectiv, $112,7 \pm 1,21 \mathrm{vs} .18,40 \pm 0,87 \mathrm{mg}$ cianidol/g extract), însă ambele extracte au avut o acțiune promițătoare de a neutraliza radicalul liber DPPH $\left(\mathrm{EC}_{50}=15,56 \pm 0,03\right.$ respectiv 47,18 $\left.\pm 0,12 \mu \mathrm{g} / \mathrm{mL}\right)$. Pentru a investiga dacă este adecvată administrarea extractelor CP și VO pe calea sublinguală sau dermică, au fost realizate studii de permeație și penetrație în celule de difuzie Franz. Polifenolii din ambele extracte au dovedit o capacitate de transfer mai mare prin membrana sublinguală porcină $(71,93 \%$ și respectiv, $62,65 \%$ polifenoli în compartimentul receptor) comparativ cu membrana din piele de pui (54,48\% şi respectiv, 39,42\% polifenoli în compartimentul receptor). Rezultatele studiului susțin posibilitatea de formulare a extractelor în forme farmaceutice oromucozale.

Keywords: Viburnum opulus, Crataegus pentagyna, permeation study, antioxidant activity

\section{Introduction}

In the past several years, researchers have shown an increasing interest towards the bioavailability of polyphenols. After oral administration, polyphenols reach the gastrointestinal system where small molecules such as caffeic acid, epicatechin, quercetin, genistein, naringenin, gallic acid or epigallocatechin can be directly absorbed by passive diffusion, while complex structures have a low absorption rate. For instance, studies reported for caffeic acid a percentage of absorption up to $95 \%$, while its ester with quinic acid (namely chlorogenic acid) reaches an absorption of only $33 \%$ [25]. Similar situations are reported for large molecules such as polymers of flavan-3-ol (proanthocyanidins). In case of proanthocyanidins, only the monomers, dimers and trimers are absorbable with very low absorption rates (less than 4\%) [17]. Glycosides of polyphenols are usually cleaved by enzymes such as $\beta$-glucosidases inside the intestinal cells, resulting in a lipophilic aglycon that can be easily absorbed by passive transport. Moreover, before reaching systemic circulation, within enterocytes, most of the polyphenolic 
aglycones are partially inactivated and undergo phase II metabolism pathways (glucuronidation, sulphation, methylation) [26]. As a result, plasma levels of polyphenols in human trials are sometimes too low to exert a biological activity. Nowadays, specific strategies are directed towards increasing the bioavailability of polyphenols by developing novel delivery systems or finding new routes for their administration. Resveratrol was previously reported to be a successful candidate for transmucosal delivery systems. A good passive diffusion through buccal mucosa was determined for this compound, relying on two important characteristics: a low molecular weight and the presence of unionized form at the physiological $\mathrm{pH}$ of saliva. Lozenges containing resveratrol formulated with a solubility enhancer such as ribose showed significantly improved pharmacokinetic parameters in human plasma in comparison with resveratrol. The maximum plasma level of resveratrol $(328 \pm 5 \mathrm{ng} / \mathrm{mL})$ was obtained after only 15 minutes with lozenges placed between gum and cheek, while the oral administration of resveratrol led to maximum plasma levels of $25-43.8 \mathrm{ng} / \mathrm{mL}$ after an interval of 0.8 to $1 \mathrm{~h}$. Besides the increase in solubility, avoidance of the first pass effect also improves resveratrol pharmacokinetics as it reduces the glycosylation and sulphation rates of resveratrol [5]. Quercetin is another example of a polyphenol whose bioavailability was increased by a novel formulation obtained by coaxial electrospraying. Thus, microparticles containing polyvinylpyrrolidone (PVP) and quercetin in the core, covered by PVP/sodium dodecyl sulphate/sucralose shells, were able to increase ten times the permeation rate through sublingual mucosa compared to quercetin powder and to release the incorporated quercetin in less than one minute [15]. Such novel sublingual delivery systems can enhance the permeation properties of polyphenols with low bioavailability.

Viburnum opulus L. (European cranberrybush, family Adoxaceae) fruits were traditionally used in the treatment of hypertension [28]. We have recently reported that the hydroacetonic fruit extract of $V$. opulus can produce vasodilation of the rat aortic rings [6]. Other studies outlined that the juice and ethanolic fruit extract of $V$. opulus possess antimicrobial properties against Gram-positive and Gram-negative bacteria [8]. Previous studies on Crataegus pentagyna Waldst. et Kit. ex Willd. (small-flowered black hawthorn, Rosaceae) reported the antiarrhythmic activity of the hydro-ethanolic leaf extract [18], in vivo antihypoxic effect of the hydroacetomethanolic fruit extract [10] and ex vivo vasorelaxant properties of the ethyl acetate leaf, flower and fruit extracts [7]. All these effects were mainly correlated with the presence of polyphenols. For example, the hydroacetonic extract of $V$. opulus fruits contains flavonoids (rutin, quercetin rhamnoside), phenolic acids (coumaroyl quinic acid, cryptoclorogenic acid) and proantho- cyanidins (procyanidin dimer and trimer) [6], while the ethyl acetate extract of $C$. pentagyna leaves is characterised by the presence of flavonoids (rutin, quercetin, apigenin- $C$-hexoside), phenolic acids (caffeoylthreonic acid, protocatechuic acid) and proanthocyanidins (procyanidin trimer, properlargonidin dimer) [7]. Both V. opulus and C. pentagyna extracts contain significant amounts of chlorogenic acid (30.89 and $17.57 \mathrm{mg} / \mathrm{g}$, respectively) [6, 7]. However, in case of polyphenol-rich extracts, one of the main challenges regarding the translation of in vitro effects to in vivo is related to the limited oral bioavailability of polyphenols.

The present study aimed to investigate the total phenolic, flavonoid and proanthocyanidin contents in C. pentagyna leaf $(\mathrm{CP})$ and $V$. opulus fruit (VO) extracts and to assess their antioxidant activity. In addition, some pharmacokinetic properties important for the further development of dosage forms were explored by in vitro permeation and penetration studies on porcine sublingual membrane and chicken skin. To the best of our knowledge, there are no previous permeation and penetration studies through different biological membranes on either $C$. pentagyna leaf or $V$. opulus fruit extracts. However, there is a study reporting an absorption rate of only $31 \%$ for the oligomeric proanthocyanidin fraction isolated from other Crataegus species after oral administration in mice [13].

\section{Materials and Methods}

Materials

Aluminium chloride, $(+)$-catechin, dimethyl sulfoxide (DMSO), Folin-Ciocâlteu reagent, chlorogenic acid, sodium hydroxide, hydrochloric acid, $n$-butanol, sodium nitrite, sodium carbonate, ammonium iron(III) sulphate dodecahydrate, 2,2-diphenyl-1-picrylhydrazyl (DPPH) were purchased from Sigma-Aldrich (Steinheim, Germany). Ethyl acetate was acquired from Riedel-de Haën (Seelze, Germany), while the other solvents were purchased from Sigma-Aldrich (Steinheim, Germany).

Plant material and extraction

V. opulus fruits (collected in Suceava County, Romania in October 2017) and C. pentagyna leaves (collected in Tulcea County, Romania in May 2016) were extracted as previously reported $[6,7]$. In brief, frozen $V$. opulus fruits (without kernels) were subjected to ultrasonic extraction with acetone:water:acetic acid (80:19.5:0.5, $\mathrm{v} / \mathrm{v} / \mathrm{v})$, delipidated with diethyl ether and concentrated to dryness (yield 11.5\%) [6]. Dried C. pentagyna leaves were delipidated with hexane and extracted with acetone:water $(7: 3, \mathrm{v} / \mathrm{v})$. The hydroacetonic extract was successively partitioned in chloroform and ethyl acetate. The ethyl acetate fraction was concentrated to dryness (yield 4.25\%) [7].

In vitro diffusion study

The in vitro diffusion study was performed using Franz vertical diffusion cells of $1.5 \mathrm{~cm}$ internal diameter 
FARMACIA, 2020, Vol. 68, 4

(Orchid Scientific Ltd., Ambad, India). The assays were performed on both porcine sublingual mucosa/ epithelium and chicken skin that were purchased fresh from a local slaughterhouse. The sublingual mucosa was detached from the ventral surface of fresh porcine tongue, after the muscle and connective tissues were removed with a scalpel. The chicken skin was obtained from fresh chicken legs, excised from areas without pores, followed by the removal of fatty tissue. These membranes were cut in areas of $4 \mathrm{~cm}^{2}$ and placed in $10 \%$ glycerine before being mounted between the donor and receptor compartments. Sublingual membranes were characterized by a thickness of $0.4 \pm 0.05 \mathrm{~mm}$, while the mean thickness of chicken skin membranes was $0.9 \pm 0.1 \mathrm{~mm}$. Diffusion cells were connected to a thermostated water bath at $36.5 \pm 0.5^{\circ} \mathrm{C}$ and the homogeneity of receptor fluid was maintained by magnetic stirring. Each receptor compartment was filled with $12 \mathrm{~mL}$ of isotonic phosphate buffer $\mathrm{pH} 7.4$ solution and the rotation was set at $100 \mathrm{rpm}$. During the diffusion process, $500 \mu \mathrm{L}$ sample aliquots were withdrawn at regular time intervals for a period of 4 hours and replaced with the same volume of fresh medium. The sample aliquots were analysed in terms of total phenolic content using the Folin-Ciocâlteu reagent as described below. At the end of experiment, the membranes were removed and placed in DMSO and methanol 1:3 (v/v) for $24 \mathrm{~h}$; further, the filtrate was used to quantify the polyphenols retained in the membrane. The cumulative amount of polyphenols transported across the membrane $p e r \mathrm{~cm}^{2} v s$. incubation time was plotted in GraphPad ${ }^{\circledR}$. The steady-state flux, lag time and permeability coefficients were calculated in MatLab ${ }^{\circledR}$ according to Fick's first law of diffusion $[23,29]$. The experiments were conducted in duplicate. Total phenolic content

The total phenolic (TP) content of both extracts was determined using the Folin-Ciocâlteu reagent [12]. The absorbance was measured at $765 \mathrm{~nm}$ using a SPECORD 210 PLUS spectrophotometer (Analytik Jena, Germany) and the TP content was calculated from the calibration curve using chlorogenic acid as standard $(2-15 \mu \mathrm{g} / \mathrm{mL})$. This method was used to quantify the total phenolic content in Franz diffusion cell.

In-house validation of the total phenolic quantification method

We used Folin-Ciocâlteu assay as a simple and lowcost method to quantify the polyphenols that were able to penetrate and permeate the biological membranes based on chlorogenic acid calibration curve. For validation, we took into consideration the following parameters: linearity (evaluated according to the calibration curve and its correlation coefficient $\mathrm{R}^{2}$ ), limit of quantification (LQ) and limit of detection (LD) (calculated according to International Council for Harmonisation $(\mathrm{ICH})$ guidelines: $\mathrm{LQ}=10 \times \sigma / S$, $\mathrm{LD}=3.3 \times \sigma / S$, where $\sigma$ is the standard deviation of the intercept and $S$ is the slope of the curve), repeatability or intra-day precision (evaluated by measuring the absorbance of six replicates of the concentration of $6 \mu \mathrm{g} / \mathrm{mL}$ ), intermediate precision (inter-day precision) (determined by recording the absorbance of three concentrations of chlorogenic acid $(3,6$ and $10 \mu \mathrm{g} / \mathrm{mL})$ in the same laboratory by one person on three different days), accuracy (determined by quantification of total phenolic content of the standard solution (chlorogenic acid) at three different concentration levels of 80 , 100 and $120 \%$, namely $6.4,8$ and $9.6 \mu \mathrm{g} / \mathrm{mL}$ ). The mean recovery percentages and relative standard deviation (RSD) \% were calculated [16, 30].

Total flavonoid content

The quantification of total flavonoid (TF) content was based on the formation of flavonoid-aluminium chloride complexes. The absorbance was recorded at $510 \mathrm{~nm}$ and the results were expressed in $\mathrm{mg} \mathrm{(+)-}$ catechin equivalents/g of dry extract [12, 27].

Total proanthocyanidin content

The total proanthocyanidin (TPA) content was estimated using $n$-butanol/ $/ \mathrm{HCl}$ method. The TPA content, expressed in $\mathrm{mg}$ cyanidin/g of dry extract, was calculated using the molar absorptivity of cyanidin $(\varepsilon=17.360 \mathrm{~L} /$ $(\mathrm{mol} \times \mathrm{cm}))[12,21]$.

DPPH free radical scavenging assay

The free radical scavenging activity was evaluated by detecting the decrease of the absorbance of a methanolic DPPH solution at $517 \mathrm{~nm}$ in the presence of the extract according to a previously described methodology [4]. The results were expressed as effective concentration required scavenging $50 \%$ of the amount of DPPH free radical $\left(\mathrm{EC}_{50}\right)$. Chlorogenic acid and quercetin were used as positive controls.

Statistical analysis

All results were expressed as mean \pm SD. Statistical analysis was performed with Prism ${ }^{\circledR}$ (GraphPad software, version 5.03). Plots of the permeation profiles were compared by linear regression analysis. Differences between two values were evaluated by unpaired Student's $t$ test. Values of $\mathrm{p}<0.05$ were considered statistically significant.

\section{Results and Discussion}

As our previous investigations showed potent endotheliumdependent vasorelaxant activity $[6,7]$ and antiplatelet effects (unpublished data) for $C$. pentagyna leaf and $V$. opulus fruit extracts, we chose these two extracts for further investigations focusing on the development of dosage forms with cardiovascular benefits. As oxidative stress plays a significant role in the pathogenesis of many cardiovascular diseases (atherosclerosis, ischemic stroke, hypertension) [2,19], we evaluated the antioxidant capacity of both extracts using the DPPH assay.

$\mathrm{CP}$ and VO extracts exerted potent DPPH radical scavenging effects as resulted from their low $\mathrm{EC}_{50}$ 
FARMACIA, 2020, Vol. 68, 4

values $(15.56 \pm 0.03$ and $47.18 \pm 0.12 \mu \mathrm{g} / \mathrm{mL}$, respectively), but still less pronounced than those of reference antioxidants such as quercetin and chlorogenic acid $\left(\mathrm{EC}_{50}=3.01 \pm 0.01\right.$ and $9.97 \pm 0.02 \mu \mathrm{g} / \mathrm{mL}$, respectively). While $\mathrm{CP}$ extract was able to reach a maximum scavenging activity of $98.5 \%$ at $340 \mu \mathrm{g} / \mathrm{mL}$, VO extract was less potent exerting a maximum scavenging activity of $92.5 \%$ at the same concentration (Figure 1). The greater antioxidant potency of CP extract can be ascribed mainly to its higher total phenolic, flavonoid and proanthocyanidin contents in comparison with VO extract (Table I). A hydromethanolic extract of $C$. pentagyna leaves was reported to contain lower total phenolic, flavonoid and proanthocyanidin contents (206.94 mg gallic acid equivalents, $57.08 \mathrm{mg}$ catechin and $68.92 \mathrm{mg}$ cyaniding/g of dry extract, respectively) [12] in comparison with $C$. pentagyna leaf extract investigated in the present study $(901.12 \mathrm{mg}$ chlorogenic acid equivalents, $416.68 \mathrm{mg}$ catechin equivalents and $112.7 \pm 1.21 \mathrm{mg}$ cyanidin/g of dry extract, respectively). A hydroethanolic extract of $V$. opulus fruits had lower total phenolic, flavonoid and proanthocyanidin contents (3.73 mg of gallic acid equivalents, $2.01 \mathrm{mg}$ of catechin equivalents and $0.52 \mathrm{mg}$ of cyanidin equivalents/g of dry extract, respectively) [20] in comparison with $V$. opulus fruit extract under study $(231.15 \mathrm{mg}$ chlorogenic acid equivalents, $95.33 \mathrm{mg}$ catechin equivalents and $18.40 \mathrm{mg}$ cyanidin/g of dry extract, respectively). It is obvious that the extraction and purification procedures used in the present study led to extracts enriched in polyphenols. A water extract obtained from $V$. opulus fruits showed lower DPPH scavenging activity $\left(\mathrm{EC}_{50}=\right.$ $57 \mu \mathrm{g} / \mathrm{mL})$ [3] than VO extract $\left(\mathrm{EC}_{50}=47.18 \mu \mathrm{g} / \mathrm{mL}\right)$. The juice obtained from the fruits of different $V$. opulus genotypes, having a total phenolic content ranging from 5.47 to $10.61 \mathrm{mg}$ of gallic acid equivalents/g of juice, showed DPPH scavenging effects of $70.2-77.5 \%$ [14]. However, due to the different experimental protocols, a comparison of these results with the ones obtained in our study is not feasible.

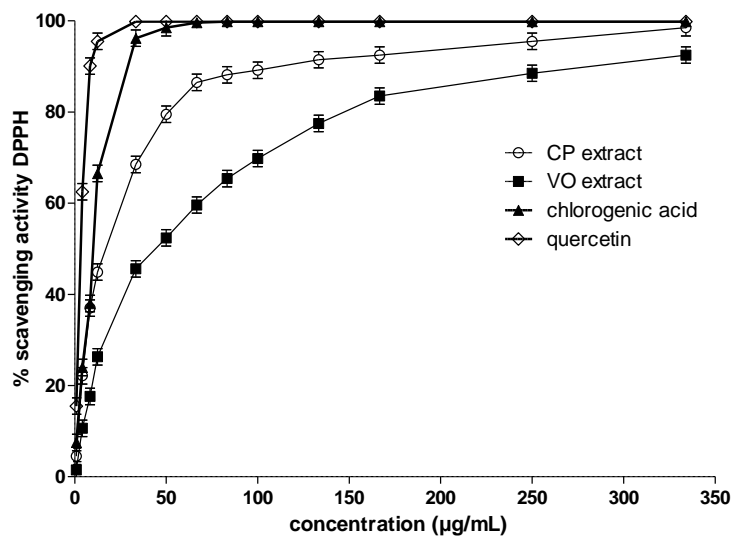

Figure 1.

DPPH scavenging effects of $C$. pentagyna leaf (CP) and $V$. opulus fruit (VO) extracts

Total phenolic (TP), total flavonoid (TF) and total proanthocyanidin (TPA) contents of C. pentagyna leaf (CP)

Table I and $V$. opulus fruit (VO) extracts

\begin{tabular}{|l|c|c|c|}
\hline \multicolumn{1}{|c|}{ Sample } & $\begin{array}{c}\text { TP } \\
\text { (mg chlorogenic acid equivalents/g extract) }\end{array}$ & $\begin{array}{c}\text { TF } \\
\text { (mg catechin equivalents/g extract) }\end{array}$ & $\begin{array}{c}\text { TPA } \\
\text { (mg cyanidin/g extract) }\end{array}$ \\
\hline CP extract & $901.12 \pm 3.23^{\mathrm{a}}$ & $416.68 \pm 2.03^{\mathrm{c}}$ & $112.7 \pm 1.21^{\mathrm{e}}$ \\
\hline VO extract & $231.15 \pm 1.53^{\mathrm{b}}$ & $95.33 \pm 0.95^{\mathrm{d}}$ & $18.40 \pm 0.87^{\mathrm{f}}$ \\
\hline
\end{tabular}

Values represent mean $\pm \mathrm{SD}$ of the determinations performed in triplicate. Values with a statistical significance $(\mathrm{p}<0.05)$ are annotated with different letters.

The calibration curve for total phenolic content showed linearity in the concentration range of $2-15 \mu \mathrm{g} / \mathrm{mL}$ and the correlation coefficient was higher than 0.999 . The detection and quantification limits were 0.985 and $2.987 \mu \mathrm{g} / \mathrm{mL}$, respectively and these values were below the minimum concentration of polyphenols (expressed in chlorogenic acid equivalents) quantified in the Franz diffusion cell. For the intra-day and interday precision, RSD (\%) were $1.603 \%$ and $2.654 \%$, respectively. The mean recovery percentages varied between $98.41 \%-103.40 \%$, thus being in the adequate range of $95-105 \%$. These data confirm that the method used for the quantification of total phenolic content is precise and accurate.

As shown in Figure 2A, in the first ten minutes, CP extract presented a higher amount of polyphenols permeated per unit area of chicken skin (1140.75 $\mu \mathrm{g} / \mathrm{cm}^{2}$ ) compared to porcine sublingual membrane $\left(568.24 \mu \mathrm{g} / \mathrm{cm}^{2}\right)$. However, in the next 20 minutes, the permeability of polyphenols of CP extract through sublingual membrane was notably accelerated; thus, after 30 minutes, the amount of polyphenols permeated across the sublingual membrane $\left(1698.97 \mu \mathrm{g} / \mathrm{cm}^{2}\right)$ exceeded the one permeated across the skin membrane $\left(1614.94 \mu \mathrm{g} / \mathrm{cm}^{2}\right)$. In the next stages of the experiment, the permeation speed of polyphenols of CP extract across the sublingual membrane had a relatively constant increase rate $\left(300-400 \mu \mathrm{g} / \mathrm{cm}^{2}\right.$ every 30 minutes), while for the skin membrane, the increase rate was slower $\left(100-150 \mu \mathrm{g} / \mathrm{cm}^{2}\right.$ every 30 minutes). As a consequence of this behaviour, the final results of the in vitro permeability test after 240 minutes revealed a superior permeability of polyphenols of CP extract through sublingual $\left(3301.73 \mu \mathrm{g} / \mathrm{cm}^{2}\right) v s$. skin $(2538.61$ $\mu \mathrm{g} / \mathrm{cm}^{2}$ ) pathway. All these data are supported by the percentage of polyphenols of CP extract in the receptor compartment, as well as by the permeability coefficient and flux across the membranes (Table II). 
Moreover, the permeation through sublingual membrane reached faster the steady-state, while in the case of skin membrane; the steady state couldn't be reached within four hours (Figure 2A).

The polyphenols of VO extract had a different permeation profile than the ones of $\mathrm{CP}$ extract (Figure 2B). For the first ten minutes, the polyphenols of VO extract presented a higher permeation through sublingual membrane than the one through the skin membrane $\left(473.47 \mu \mathrm{g} / \mathrm{cm}^{2} v s .137 .35 \mu \mathrm{g} / \mathrm{cm}^{2}\right)$. For the next 20 minutes, it has been recorded a more accelerated permeation rate through the sublingual membrane than skin membrane $\left(200-400 \mu \mathrm{g} / \mathrm{cm}^{2} v s .80-130\right.$ $\mu \mathrm{g} / \mathrm{cm}^{2}$ every ten minutes). Thus, at 30 minutes, the amount of polyphenols permeated per unit area of sublingual membrane $\left(1019.65 \mu \mathrm{g} / \mathrm{cm}^{2}\right)$ surpassed the amount of polyphenols permeated through skin $\left(249.50 \mu \mathrm{g} / \mathrm{cm}^{2}\right)$. For the following stages of the experiment, the permeation rates remained constant for the two membranes and, at the end of the permeation study; we concluded that the permeation through the sublingual membrane was superior to the one through skin. These results were confirmed by other permeation parameters such as the permeability coefficient, percentage of polyphenols in the receptor compartment and values of the flux across membranes (Table II).

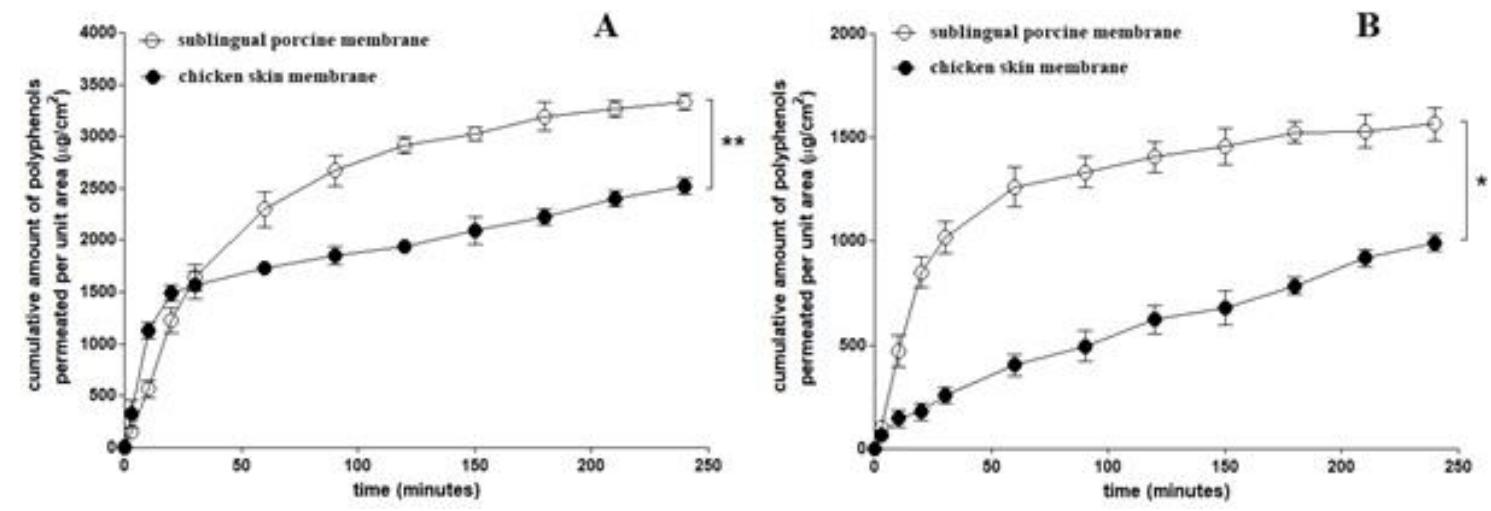

Figure 2.

In vitro permeation kinetics of polyphenols of $C$. pentagyna leaf $(\mathrm{CP})$ extract $(\mathrm{A})$ and $V$. opulus fruit (VO) extract (B) across the porcine sublingual and chicken skin membranes, ${ }^{*} \mathrm{p}<0.5,{ }^{*} \mathrm{p}<0.001$

Table II

Parameters for permeation and diffusion of polyphenols of $C$. pentagyna leaf (CP) and V. opulus fruit (VO) extracts through biological membranes

\begin{tabular}{|c|c|c|c|c|c|c|c|}
\hline Extract & \begin{tabular}{|l} 
Biological \\
membrane
\end{tabular} & $\begin{array}{c}\text { Flux } \\
(\mu \mathrm{g} / \mathrm{cm} \times \mathbf{h})\end{array}$ & $\begin{array}{l}\text { Lag time } \\
\text { (h) }\end{array}$ & \begin{tabular}{|l|} 
Permeabilit \\
y coefficient \\
$\left(x 10^{-3} \mathrm{~cm} / \mathrm{h}\right)$
\end{tabular} & \begin{tabular}{|c|}
$\begin{array}{c}\text { Diffusion } \\
\text { coefficient } \\
\left(\times 10^{3} \mathrm{~cm}^{2} / \mathrm{h}\right)\end{array}$ \\
\end{tabular} & $\begin{array}{c}\text { Maximum percentage } \\
\text { of polyphenols in the } \\
\text { receptor compartment } \\
(\%)\end{array}$ & $\begin{array}{c}\text { Total percentage } \\
\text { of polyphenols } \\
\text { in the membrane } \\
(\%)\end{array}$ \\
\hline \multirow[t]{2}{*}{$\mathrm{CP}$} & $\begin{array}{c}\text { porcine } \\
\text { sublingual } \\
\text { membrane } \\
\end{array}$ & $78.54 \pm 5.74^{\mathrm{a}}$ & $0.17 \pm 0.01^{\mathrm{a}}$ & $4.85 \pm 0.51^{\mathrm{a}}$ & $0.86 \pm 0.15^{\mathrm{a}}$ & $71.93 \pm 2.38^{a}$ & $14.68 \pm 1.31^{\mathrm{a}}$ \\
\hline & $\begin{array}{c}\text { chicken skin } \\
\text { membrane }\end{array}$ & $63.29 \pm 4.41^{\mathrm{b}}$ & $0.31 \pm 0.02^{b}$ & $3.92 \pm 0.45^{\mathrm{b}}$ & $7.94 \pm 0.29^{b}$ & $54.48 \pm 3.51^{\mathrm{b}}$ & $21.16 \pm 2.23^{b}$ \\
\hline \multirow[t]{2}{*}{ VO } & $\begin{array}{c}\text { porcine } \\
\text { sublingual } \\
\text { membrane }\end{array}$ & $32.13 \pm 3.57^{c}$ & $0.16 \pm 0.05^{\mathrm{a}}$ & $3.65 \pm 0.21^{\mathrm{b}}$ & $0.74 \pm 0.12^{\mathrm{c}}$ & $62.65 \pm 2.72^{c}$ & $18.17 \pm 1.52^{\mathrm{b}}$ \\
\hline & $\begin{array}{c}\text { chicken skin } \\
\text { membrane }\end{array}$ & $25.31 \pm 2.85^{\mathrm{d}}$ & $0.36 \pm 0.04^{b}$ & $2.87 \pm 0.33^{\mathrm{c}}$ & $8.43 \pm 0.38^{b}$ & $39.42 \pm 3.35^{\mathrm{d}}$ & $27.50 \pm 2.91^{\mathrm{c}}$ \\
\hline
\end{tabular}

Values represent mean \pm SD of two different experiments. Statistically significant differences $(\mathrm{p}<0.05)$ between values from a column $(\mathrm{p}<$ $0.05)$ are annotated with different letters.

According to the results in Table II, the polyphenols tend to accumulate more in the skin layers comparing to the sublingual mucosa suggesting a high penetration through this type of membrane. These results were confirmed by the determination of polyphenol percentages in the membranes at the end of the experiment as well as by the diffusion coefficient. Interaction with the membranes can be explained by the presence of proanthocyanidins that are known to possess high binding affinity to proteins [9]. Procyanidin dimers were previously tentatively identified in $\mathrm{VO}$ and $\mathrm{CP}$ extracts $[6,7]$. The presence of extract compounds inside the skin is important if extracts will be designed to be used in skin infections; in this case, their persistence could increase their antimicrobial efficacy. Other studies confirmed that polyphenols such as resveratrol, curcumin 
and catechin can interact with the phospholipids present in the skin membrane thereby favouring the formation of a skin reservoir [1]. Polyphenols such as epicatechin, chlorogenic acid and quercetin were previously identified and quantified in $\mathrm{CP}$ and $\mathrm{VO}$ extracts $[6,7]$. These polyphenols were reported to exert antimicrobial effects [11].

On contrast, in case of the sublingual administration of extracts, the aim is to have a low lag time with a rapid onset of action and more specifically, a reduced amount of polyphenols retained in the membrane. This can be correlated with a rapid transfer of the active compounds inside the blood stream which, according to our permeability studies, can be accomplished by polyphenols of $\mathrm{CP}$ and VO extracts. The sublingual membrane is thinner than the skin membrane and therefore both extracts were able to surpass this membrane in a greater extend compared to skin membrane. Besides, the epithelial characteristics of the sublingual mucosa can favour the fast transfer of polyphenols into the blood stream [24].

The ability of the polyphenols of $\mathrm{CP}$ and VO extracts to permeate both membranes might be the consequence of their amphiphilic characteristics. Thus, not only the capacity of the polyphenols to easily penetrate the hydrophobic bilayer of the biological membranes, but also their ability to dissolve into the aqueous receptor medium have contributed to a higher permeation capacity across biological membranes. Another factor that might influence the permeation capacity is linked to the presence of polyphenols in the aglycone forms which are more lipophilic than the glycosylated ones [22].

\section{Conclusions}

The extract obtained from Crataegus pentagyna leaves was characterized by higher polyphenolic, flavonoid and proanthocyanidin contents than Viburnum opulus fruit extract. Both extracts exhibited a potent scavenging activity against DPPH free radical. The permeation profiles offered useful information for pre-formulation studies; both extracts had a good permeability through the sublingual membrane supporting the idea that they are good candidates for the development of oromucosal dosage forms with accelerated release. In addition, Crataegus pentagyna leaf extract showed a good, but slow permeability through the skin membrane, this behaviour being appropriate for the formulation of modified release semisolid dosage forms.

\section{Acknowledgement}

This research was financially supported by "Grigore T. Popa" University of Medicine and Pharmacy Iași, Romania, grant no. 7626/18.04.2019.

\section{Conflict of interest}

The authors declare no conflict of interest.

\section{References}

1. Abla, MJ, Banga AK, Quantification of skin penetration of antioxidants of varying lipophilicity. Int J Cosmet Sci,. 2013; 35(1): 19-26.

2. Allen CL, Bayraktutan U, Oxidative stress and its role in the pathogenesis of ischaemic stroke. Int $J$ Stroke, 2009; 4(6): 461-470.

3. Altun ML, Çitoğlu GS, Yilmaz BS, Çoban T, Antioxidant properties of Viburnum opulus and Viburnum lantana growing in Turkey. Int J Food Sci Nutr., 2008; 59(3): 175-180.

4. Aprotosoaie AC, Mihai CT, Vochita G, Rotinberg P, Trifan A, Luca SV, Petreus T, Gille E, Miron A, Antigenotoxic and antioxidant activities of a polyphenolic extract from European Dracocephalum moldavica L. Ind Crops Prod., 2016; 79: 248-257.

5. Blanchard OL, Friesenhahn G, Javors MA, Smoliga JM, Development of a lozenge for oral transmucosal delivery of trans-resveratrol in humans: Proof of concept. PLoS One, 2014; 9(2): e90131: 1-8.

6. Bujor A, Miron A, Luca SV, Skalicka-Wozniak K, Silion M, Ancuceanu R, Dinu M, Girard C, Demougeot $\mathrm{C}$, Totoson $\mathrm{P}$, Metabolite profiling, arginase inhibition and vasorelaxant activity of Cornus mas, Sorbus aucuparia and Viburnum opulus fruit extracts. Food Chem Toxicol., 2019; 133: 110764: 1-10.

7. Bujor A, Miron A, Luca SV, Skalicka-Wozniak K, Silion M, Trifan A, Girard C, Demougeot C, Totoson $\mathrm{P}$, Vasorelaxant effects of Crataegus pentagyna: Links with arginase inhibition and phenolic profile. $J$ Ethnopharmacol., 2020; 252: 112559: 1-8.

8. Česoniene L, Daubaras R, Viškelis P, Šarkinas A, Česonienė L, Daubaras R, Viškelis P, Šarkinas A, Determination of the Total Phenolic and Anthocyanin Contents and Antimicrobial Activity of Viburnum Opulus Fruit Juice. Plant Foods Hum Nutr., 2012; 67: 256-261.

9. Dai T, Chen J, McClements DJ, Hu P, Ye X, Liu C, Li T, Protein-polyphenol interactions enhance the antioxidant capacity of phenolics: Analysis of rice glutelin-procyanidin dimer interactions. Food Funct., 2019; 10(2): 765-774.

10. Ebrahimzadeh MA, Khalili M, Jafari N, Zareh G, Farzin D, Amin G, Antihypoxic activities of Crataegus pentaegyn and Crataegus microphylla fruits-an in vivo assay. Braz J Pharm Sci., 2018; 54(2): e17363: 1-5.

11. Fu L, Lu WQ, Zhou XM, Phenolic Compounds and In Vitro Antibacterial and Antioxidant Activities of Three Tropic Fruits: Persimmon, Guava, and Sweetsop. Biomed Res Int, . 2016; 2016: 4287461: 1-10.

12. Giurescu Bedreag FC, Trifan A, Bucur AL, Arcus M, Tebrencu C, Miron A, Costache I, Chemical and antioxidant studies on Crataegus pentagyna leaves and flowers. Rom Biotechnol Lett., 2014; 19(6): 9859-9867.

13. Holubarsch CJF, Colucci WS, Eha J, Benefit-Risk Assessment of Crataegus Extract WS 1442: An Evidence-Based Review. Am J Cardiovasc Drugs, 2018; 18(1): 25-36.

14. Kraujalytė V, Venskutonis PR, Pukalskas A, Česoniené L, Daubaras R, Antioxidant properties and polyphenolic compositions of fruits from different European 
cranberrybush (Viburnum opulus L.) genotypes. Food Chem., 2013; 141(4): 3695-3702.

15. Li C, Yu DG, Williams GR, Wang ZH, Fast-Dissolving Core-Shell Composite Microparticles of Quercetin Fabricated Using a Coaxial Electrospray Process. PLoS One, 2014; 9(3): e92106: 1-9.

16. Luca SV, Miron A, Aprotosoaie AC, Mihai CT, Vochita G, Gherghel D, Ciocarlan N, Skalicka-Wozniak K, HPLC-DAD-ESI-Q-TOF-MS/MS profiling of Verbascum ovalifolium Donn ex Sims and evaluation of its antioxidant and cytogenotoxic activities. Phytochem Anal., 2019; 30(1): 34-45.

17. Luca SV, Macovei I, Bujor A, Miron A, SkalickaWoźniak K, Aprotosoaie AC, Trifan A, Bioactivity of dietary polyphenols: The role of metabolites. Crit Rev Food Sci Nutr., 2020; 60(4): 626-659.

18. Pahlavan S, Tousi MS, Ayyari M, Alirezalu A, Ansari H, Saric T, Baharvand H, Effects of hawthorn (Crataegus pentagyna) leaf extract on electrophysiologic properties of cardiomyocytes derived from human cardiac arrhythmia-specific induced pluripotent stem cells. FASEB J., 2018; 32(3): 1440-1451.

19. Pîrvu L, Sha'at F, Păvăloiu R, Udeanu DI, Albu B, Studies on Acinos alpinus L.: Polyphenols and terpenoids compounds profile, antimicrobial activity, antioxidant effect and release experiments on the ethanol and propylene glycol extracts. Farmacia, 2019; 67(6): 1025-1033.

20. Polka D, Podsędek A, Koziołkiewicz M, Comparison of Chemical Composition and Antioxidant Capacity of Fruit, Flower and Bark of Viburnum opulus. Plant Foods Hum Nutr., 2019; 74: 436-442.

21. Porter LJ, Hrstich LN, Chan BG, The conversion of procyanidins and prodelphinidins to cyanidin and delphinidin. Phytochemistry, 1986; 25(1): 223-230.

22. Ratz-Łyko A, Arct J, Majewski S, Pytkowska K, Influence of Polyphenols on the Physiological Processes in the Skin. Phyther Res., 2015; 29(4): 509-517.
23. Santana de Freitas-Blanco V, Franz-Montan M, Groppo FC, de Carvalho JE, Figueira GM, Serpe L, Oliveira Sousa IM, Guilherme Damasio VA, Yamane LT, de Paula E, Ferreira Rodrigues RA, Development and Evaluation of a Novel Mucoadhesive Film Containing Acmella oleracea Extract for Oral Mucosa Topical Anesthesia. PLoS One, 2016; 11(9): e0162850: 1-18.

24. Sattar M, Sayed OM, Lane ME, Oral transmucosal drug delivery - Current status and future prospects. Int J Pharm., 2014; 471(1-2): 498-506.

25. Scalbert A, Morand C, Manach C, Rémésy C, Absorption and metabolism of polyphenols in the gut and impact on health. Biomed Pharmacother., 2002; 56(6): 276282.

26. Teng H, Chen L, Polyphenols and bioavailability: An update. Crit Rev Food Sci Nutr., 2019; 59(13): 20402051.

27. Trifan A, Sava D, Bucur LA, Mihai CT, Aprotosoaie AC, Cioancă O, Hăncianu M, Miron A, Antioxidant and cytotoxic activities of Phyllophora pseudoceranoides (Gmelin) New. et Tayl. Farmacia, 2016; 64(4): 502506.

28. Velioglu YS, Ekici L, Poyrazoglu ES, Phenolic composition of European cranberrybush (Viburnum opulus L.) berries and astringency removal of its commercial juice. Int J Food Sci Technol., 2006; 41: 1011-1015.

29. Zillich OV, Schweiggert-Weisz U, Hasenkopf K, Eisner $\mathrm{P}$, Release and in vitro skin permeation of polyphenols from cosmetic emulsions. Int J Cosmet Sci., 2013; 35(5): 491-501.

30. *** ICH Harmonized Tripartite Guidelines Q2(R1). Validation of analytical procedures: text and methodology Q2(R1) 2005. Geneva, 1-13. 